С. А. Бузько

\title{
КНИЖНА ЛЕКСИКА В ТЕКСТАХ УКРАЇНСЬКОЇ ПОСТМОДЕРНОЇ ПРОЗИ (ФУНКЦІОНАЛЬНО- СТИЛІСТИЧНИЙ АСПЕКТ)
}

Бузько С. А. Книжна лексика в текстах української постмодерної прози (функціонально-стилістичний аспект).

У статті описано функціонально-стилістичні особливості суспільнополітичної, науково-термінологічної та поетичної лексики, яка використовується в текстах української постмодерної прози.

Ключові слова: суспільно-політична лексика, науково-термінологічна лексика, поетизми, стилістичний ефект, українська постмодерна проза. 
Бузько С. А. Книжная лексика в текстах украинской постмодернистской прозы (функционально-стилистический аспект).

В статье описаны функционально-стилистические особенности общественнополитической, научно-терминологической и поэтической лексики, которая используется в текстах украинской постмодернистской прозы.

Ключевые слова: общественно-политическая лексика, научнотерминологическая лексика, поэтизмы, стилистический эффект, украинская постмодернистская проза.

Buzko S. A. Bookish vocabulary in the texts of Ukrainian postmodern prose (a functional-stylistic aspect).

The article presents the functional-stylistic features of social-political vocabulary and scientic-terminological lexicon which function in the texts of Ukrainian postmodern prose.

Key words: social-political vocabulary, scientic-terminological lexicon, functionalstylistic features, Ukrainian postmodern prose.

Книжна лексика, що в загальномовних словниках позначається відповідною ремаркою, властива писемній формі літературної мови. Цей лексичний шар активно використовується в ряді функціональних стилів писемного вияву літературної мови - науковому, публіцистичному, офіційно-діловому та художньому. Однак чітко визначеної, сталої межі між книжними словами і загальновживаними не існує, тому термін «книжна лексика» певною мірою умовний, оскільки вказує лише на переважання певних слів у функціональних стилях писемної, книжної форми літературної мови. У статті буде виявлено й описано виражальні можливості та функціонально-стилістичне призначення найбільш уживаних у сучасних художніх текстах типів книжної лексики суспільно-політичної, науково-термінологічної та поетичної.

Загальноприйнятим $є$ погляд, згідно 3 яким до категорії суспільно-політичної лексики входять слова, що стосуються політики, економіки, різних аспектів суспільного життя, проблем державного будівництва, функціонування державних і громадських інституцій тощо $[1$, с. 55-56; 12, с. 91; 2, с. 45]. Але в позиціях учених стосовно природи названого лексичного шару все ж спостерігаються деякі відмінності, що можна пояснити нечіткістю визначення меж суспільно-політичної лексики, яка тісно пов'язана 3 термінологією таких наук, як політологія, соціологія, право, філософія тощо.

Суспільно-політична лексика, яка використовується в українських постмодерних текстах, об’єднує такі лексико-тематичні групи слів: 
1) слова на позначення основних соціально-історичних категорій і понять (народ, нація, суспільство, краӥна, держава, сочіальний статус): А які повідомлення з України иікавлять західні мас-медії? Що уряд учергове вкрав у народу гроші? (20, с. 20); Укри, як і всі модерні нації, свідомо прагнули в Свропу (18, с. 16); Всі умовності створені людською психікою і уподобаннями, соціальним статусом (24, с. 16);

2) слова на позначення ідейно-політичних напрямків, течій, доктрин (марксизм, капіталізм, сочіалізм, анархізм): була саме агонія комунізму (3, с. 84); Учасники почали звинувачувати один одного в невігластві й неправильному розумінні марксизму (20, с. 72);

3) найменування, що позначають політичні партії, союзи, блоки (комуністична партія, Рух, ООН, НАТО, Свропейський Союз): уряди краӥн Свропейського Союзу вже не рекомендували свойм громадянам відвідувати ї̈ (3, с. 33); як би там не старалися інспектори ООН, $<\ldots>$ від изього в Лондоні безпечніше не стане (21, с. 78);

4) найменування на позначення осіб із погляду їх партійної належності, соціальної характеристики чи належності до різних форм державного управління (буржуй, пролетаріат, анархіст, депутат, комуніст, кадебіст): На вигляд иее був типовий пролетар незграбний, вайлуватий, з тупим і розгубленим поглядом (2, с. 25); Рома, син народного депутата (21, с. 4); Анархісти так $i$ не прийшли, зате з'явилася купа ліворадикалів (20, с. 71);

5) лексеми на позначення суспільних та політичних подій минулого й сьогодення (револючія, депортація, репресії, тероризм, демонстрачіï): передбачувана хвиля арештів <..> непередбачувано віддалялася; під загрозою репресій (3, с. 21, 94); Під час антипрезидентських протестів 2000 року Террі <..> иүілодобово знімав демонстрації (21, с. 292);

6) слова на позначення абстрактних суспільно-політичних понять (політкоректність, політична цензура, демократія, патріотизм, політична заантажованість): за відсутність «політичної заангажсованості» дорікнути було б неможливо (9, с. 36); колектив однодумиів бореться проти політичної цензури; $i$ нам, напевно, соромно одне перед одним, щзо в нас не досить геройчного патріотизму (21, с. 300, 52); Це недемократично! (14, с. 155);

7) назви понять із державно-адміністративної, фінансовоекономічної та юридичної сфер життя суспільства (закон, право, акт, злочин, договір): усе знову закрутилося: договори, сертифікати, 
цінні папери, акції, кілька ефемерних банків, трастів $і$ голдінгів (3, с. 67); Я навіть беруся вас субсидувати. Я, знаєте, відомий у смітникових колах меценат (9, с. 53); У мене постійний контракт на роботі, потім постарію, матиму британську пенсію і житиму на Мальті зі своїм чоловіком (21, с. 329).

Наявність у постмодерних текстах стількох тематичних груп суспільно-політичної лексики свідчить про певну зацікавленість письменників-постмодерністів питаннями суспільного розвитку та державного будівництва нашої країни, а також соціальними проблемами iii історичного минулого. Інколи суспільно-політична лексика допомагає відтворити епоху ідеологічного тоталітаризму, при цьому деякі слова на позначення суспільно-державного ладу та історії Радянського Союзу й епохи, що цьому передувала, набувають виразно негативного емоційнооцінного забарвлення: з того містечка <..> колись давно втікали від кагебістської облави до Києва ї̈ батьки (12, с. 79); Можливо, тому, щзо саме в цчі роки був голодомор; Шкода, звичайно, щзо Столипіна позбавили елементарного дихання, можливо, <..> він би довів до ладу земельну реформу, розпочав би масштабну індустріалізацію на колективних началах (26, с. 8, 5); слід було обганяти цілі ешелони з депортованими; двоє < .. > гебістів узяли його попід руки (3, с. 99, 87).

Однак зазвичай твори постмодернізму звернені не до минулого, а орієнтовані на різноманітні проблеми сьогодення; у ряді випадків це проблеми соціально-політичного характеру, при порушенні яких письменники використовують різні тематичні групи суспільнополітичної лексики. Зокрема, впадає в око відчутне розчарування письменників-постмодерністів у сучасному посттоталітарному устрої, відчуття тотальної порожнечі після втрати ідеологічних ілюзій. Наприклад: Макс завжди був анархістом, який не вірив у перемогу анархії, а я вірила в національну демократію, від чого тепер мені смішно (21, с. 297); 3 самого ранку я побувала на пікеті <... >. Рештки розкольного Руху щзось намагалися задекларувати. <... С Сама згадка про ции гекачепістів викликає у мене сильне почуття злості; A у нас зате соціалізм $і$ анархізм, $і$ бардак, ие теж оригінально; Далі розмова точиться на політичні теми (20, с. 46, 111, 25).

Часом використання суспільно-політичної лексики, пов'язаної 3 такими поняттями, як патріотизм, націоналізм, національна політика, підкреслює невпевненість та закомплексованість українця, який намагається бути національно свідомим у сучасних соціальних 
умовах: Я типовий невдаха. Я національно свідомий та українізований; Я невдаха-націоналіст, весь час розчаровуюсь у всіх громадських та політичних організаціях націоналістичного змісту (26, с. 68). На думку Л. Костенко, це пояснюється тим, що «замість динамічних імпульсів, які відповідали б уже новому, державному статусу нації, ій був прищеплений комплекс меншовартості, провінційності, вторинності ії мови та культури» [4, с. 457].

Використовуючи суспільно-політичну лексику, письменникипостмодерністи торкаються також таких соціальних проблем сьогодення, як тероризм, політична заангажованість сучасних мас-медіа, соціокультурний рівень бізнесової та політичної верхівки тощо. Наприклад: Чому мене може убити якийсь терорист тільки тому, щз я білий (21, с. 78); Залишається дивитися ТБ. <..> Суркіс на пресконференції перед букетом мікрофонів. Суркіс на футбольній трибуні. Суркіс шепоче щось на вухо Президенту. Суркіс та народ. <...> Медведчук. Шматок Кравчука. Медведчук у кріслі спікера... У мене ще всі вдома? (20, с. 36); працював і слюсарем, $і$ сантехніком, $і$ барменом, а тепер він займається оптимізацією податковкладень $і$ скеровуванням надлишкових капіталів (1, с. 103); Усе це наводить на особливо невтішні висновки, коли подібного киталту державницьку постать <..> зіставляєш із тутешньою навколишньою дійсністю (3, с. 25). Отже, використання суспільно-політичної лексики в художніх текстах великою мірою залежить від таких екстралінгвістичних чинників, як соціальна диференціація та психологічний стан суспільства, панівна ідеологія (провідні суспільно-політичні течії та погляди), рівень розвитку економіки.

У ряді випадків на тлі суспільно-політичної лексики автори постмодерністських творів використовують нелітературну лексику, наприклад, розмовно-просторічну та соціально марковану, удаючись таким чином до характерного для постмодернізму прийому стилістичних контрастів, що сприяє більш емоційному та експресивному висловленню думки, наприклад: але вдома, в твоїй бідній забембаній країні - краӥні урядовців в обвислих итанях $i$ всіяних лупою піджаках <..> все воно якось ні до чого не кріпилося (12, с. 48); я визнаю за людьми право на тупість, у руслі теперішньої моди на політкоректність (21, с. 112); Далі дискусія переросла в бардак, бо включились теоретики ліворадикальної думки (20, с. 72).

Зазвичай подібне поєднання різностильових елементів підкреслює іронічне звучання текстового уривку. Іронія, створена таким чином, 
представляє речі в незвичному, новому ракурсі, створює ефект відчуження, підвищує інтерес комунікантів до предмета іронічної оцінки, визначає ціннісну орієнтацію, сприяючи перетворенню суперечності на творчий пошук істини. Наприклад: Я чесно виконав свою роботу ц̆ на початку серпня отримав чесно зароблену штуку баксів, а також соціальну гарантію, тіпа, «я кореш Віті Болта», яка, за словами самого Віті, мала допомагати мені в складних життєвих ситуаціях (25, с. 59); Проте якщу западенцюю сказати про таке спостереження, він образиться $і$ почне розповідати про патріотизм Західної Украӥни $i$ скацапілість Східної, ніби патріотизм усієї Західної Украӥни вибачає mупість якогось окремого ї̈ представника (20, с. 73).

В окремих випадках суспільно-політична лексика, використовувана в постмодерних текстах, контрастує з вульгаризованою лексикою, що значно підвищує емоційність та експресивність висловлювання та посилює суб'єктивний аспект у процесі художнього відтворення адресантом (автором) навколишньої дійсності. Зазвичай це лексеми на позначення осіб із погляду їх належності до різних форм державного управління, рідше - найменування, що позначають політичні партії, союзи та блоки або слова на позначення ідейно-політичних напрямків: Отож ти циркулював поміж столами, де-не-де впізнаючи знайомі з преси й телебачення $і$ тим особливо антипатичні мордяки деяких депутатів, письменників та іншої ідеологічної сволоти (4, с. 220); НАТО - гандони! Капіталізм - гавно! - казав Рулет. - <... I президент... - тут Рулет чогось замовк» (25, с. 44).

Наведені приклади доводять, що конкретно-історичні суспільні умови безпосередньо впливають як на вибір мовленнєвих засобів, так і на характер використання тих чи тих слів.

Варто також звернути увагу на зміну емоційно-оцінного забарвлення деяких суспільно-політичних лексем, передусім тих, що стосуються політичного та ідеологічного життя колишнього Радянського Союзу й діяльності комуністичної партії. За спостереженнями В. Чабаненка, така зміна емоційно-оцінних відтінків аналізованих лексем відбувається завдяки ідеологічній переорієнтації українського суспільства [11, с. 297]. Цю думку підтверджує як суспільна мовленнєва практика, так і більшість сучасних художніх текстів; наприклад, якщо в мові колишньої партноменклатури слова більшовик, комуніст, соиіалістичний відзначалися позитивним емоційно-експресивним забарвленням, то в мовленні сучасного суспільства експресивність цих та ๑) С. А. Бузько, 2012. 
подібних слів зазвичай позначається різко негативними емоціями, наприклад: Далі маніфест на захист організації «Самостійна Україна», пропозиція дати $n<\ldots>$ и КПУ, бо вони мудаки (10, с. 185).

Інколи змінюється не лише експресивно-оцінне навантаження слова, але й лексичне значення. Наприклад, такі суспільно-політичні лексеми, як буржуй, окупант, фашист у певних комунікативно-прагматичних ситуаціях можуть втрачати своє первісне значення й уживатися задля експресивної характеристики осіб або й цілих суспільних прошарків чи народів (буржуї - про мешканців країн, де панує капіталістичний устрій; окупанти - стосовно американців; фашисти - зневажливо про сучасну молодь). Отже, спостерігається розширення лексичного значення зазначених слів: Учасники почали звинувачувати <..> пані професорку у запроданстві буржсуям; Просто пришліть мені папірець із запрошенням, чуєте, окупанти? (20, с. 72; 20, с. 19); От фашисти, не дають спокою, не вгавали сусідські бабусі (11, с. 47).

Аналіз фактичного матеріалу довів, що суспільно-політична лексика в художньому тексті - це передусім один із засобів відтворення об'єктивної дійсності та фонових знань носіїв мови певного історичного періоду. Звісно, цей процес доповнюється суб'єктивно-авторським осмисленням відтворюваної дійсності.

У словниковому складі української літературної мови вагома роль належить науково-термінологічній лексиці, кількість якої 3 розвитком науки і техніки постійно зростає. У лексикології терміном прийнято називати спеціальне слово або словосполучення, що використовується для точного вираження поняття з якої-небудь галузі знання - науки, техніки, виробництва, мистецтва тощо.

Загальновідомо, що функціонування науково-термінологічної лексики не обмежується сферами наукових досліджень. Особливістю нашого часу - часу бурхливих глобалізаційних процесів - $\epsilon$ те, що окремі групи слів термінологічної лексики швидко стають широко та активно вживаними в багатьох сферах життєдіяльності суспільства. «Термінолексика перестає бути тільки термінологічною, набуває нових переносних значень, входить у художню літературу як матеріал для нових, оригінальних тропів» [6, с. 17]. Цей тип лексики органічно входить у мову української постмодерної прози, і не лише для творення тропів, а й для реалізації інших стилістичних функцій.

За нашими підрахунками, частотність використання цього лексичного шару в аналізованих джерелах складає близько 41\% щодо 
інших типів книжної лексики. Серед науково-термінологічної лексики, яка функціонує в постмодерних текстах, наявна як загальнонаукова термінологія, поширена в багатьох сучасних галузях наукових знань (напр., синхронія, субстаниія, трансформація, узагальнення, синтез, критерій, теорія, практика тощо: Притулок теж підпорядкований якійсь логіці, але мусии пізнати ї сам. Теорія не передує практиці в цььому випадку (19, с. 90), так і спеціальна наукова термінологія, властива окремим галузям науки чи мистецтва. У складі спеціальної науково-термінологічної лексики, що використовується у творах постмодерної літератури, присутня, зокрема, термінологія:

1) лінгвістична: а коли не бавитися евфемізмами (12, с. 50); $У$ такий спосіб він мимоволі переступав заведені в цььому суто чоловічому колі неписані правила, зокрема, обов'язкову вербальну розкутість (3, с. 28);

2) музична: Я сіла за комп'ютер і красиво змахнула руками, ніби зіграла арпеджіо до мажсор (20, с. 52); Сміх не вщухав, та навіть його вже легко перекривало могутнє крещендо хору і туті духових (13, с. 13);

3) психологічна: Згадав, що завтра на ранок призначено «сеанс зрупової терапї̈» - так ие у них тут називалося (14, с. 146); У мене маніакально-депресвний психоз, нав'язливі ідеї й галюцінаці» (21, с. 100);

4) хімічна: Гемодезу, фізрозчину, глюкози - та він вже на ранок був би у формі; Трохи згодом я запитав у знайомого нарколога, щзо він думає про той сульфазин (14, с. 105; 103);

5) медична: Довелося пережити тахікардію через власний акиент (1, с. 55); Згоден на лікарню, тюрму, лоботомію (12, с. 91); Увесь час вона щиипає себе за стегно. Там велика гематома (24, с. 235);

6) фізіологічна: Намагаючись приборкати адреналін, який закипав усередині (2, с. 48); Хто не читав глибокодумних статей, у яких за допомогою слова «естроген» (жіночий статевий гормон) доводилося, щчо жінка - істота, обділена природою? (12, с. 68);

7) фізична: до того ж окуліст змушений був призначити йому по иілому додатковому діоптрію (3, с. 15); прогресуюча аморфність змушувала мене набирати тієї форми (14, с. 139);

8) природнича: Себто описати його географію, світ фльори $i$ фауни (9, с. 64);

9) спортивна: керівництво країни зробило різкий поворот від гірських лижів до веслування на байдарках $і$ каное (3, с. 66).

Виділяємо групу слів, семантично споріднену 3 суспільнополітичною лексикою, на позначення спеціальних понять зі сфери ๑) С. А. Бузько, 2012. 
суспільних наук, зокрема, економічна та фінансова термінологія, наприклад: Скоро обвалиться ринок нерухомості $(21$, с. 328$)$; я зовсім кепсько тямлю на рекламі й маркетингових технологіях (25, с. 234).

У всіх наведених вище прикладах термінолексеми використовуються в прямому значенні, виконуючи суто номінативну функцію та певною мірою підвищуючи інформативність художнього стилю мови. Однак у більшості випадків науково-термінологічна лексика вживається в текстах української постмодерної прози 3 певними стилістичними настановами. Так, інколи терміни виступають експресивними відповідниками загальновживаних слів, підкреслюючи орієнтацію постмодерних текстів на інтелектуальність, що $€$ свідченням загальної ерудованості та освіченості авторів, наприклад: мої слухачі надто спрощено сприймають алюзії та асоціативні ряди; подальші трансформації залишаємо поза ремарками (14, с. 105; 153); У самий розпал наших икільних ремінісценцій до нас підійшов симпатичний молодий чоловік (21, с.67); розтягуючи у своїх потребах усілякі фратменти і сегменти минулої цілості (4, с. 61).

У деяких випадках простежується поступовий перехід термінологічної лексики до розряду загальновживаної (процес детермінологізації), який відбувається або через розширення первісного лексичного значення термінолексем, або завдяки їх уживанню при описі звичайних побутових ситуацій: Зображення легко піддавалися селекції; Відкинувши GILLETTE як анахронізм, я подумав було вийти на автостраду; Далі з мавпячою спритністю $i$ впертістю маніакального моржа я ретельно вимиюся антибактерійним милом (14, с. 148; 106; 128); еліптичність $y$ натяках (3, с. 98); Навіть Девід поруч здавався мені не іпохондрічним ексцентриком, <..> а нормальною людиною (21, с. 132).

Подеколи слова-терміни виступають у постмодерних творах елементами мовної гри; ці факти підтверджують думку дослідників про те, що принцип гри в текстах означеного напрямку реалізується не лише на ідейно-естетичному рівні, але й на мовному також [8, с. 44; 5, с.17]. Наприклад: Думав про ї̈ серие, як воно б’'ться, про два наші серчя, про цчю поліритмію, аритмію, синхронію, котра не має иансів перетворитися на нищівний, всевладний резонанс; Старезне полотно, півторавіковий підрамник, божевільні потьмянілі фарби, рентгеноскопія безсила, спосіб трунтування, манера мазків, пірке, манту, ультразвукова діагностика, нескінченні томограми, 
електромагнітний резонанс <...> $i$ ие було останне, щзо вдалося побачити перед втратою свідомості (14, с. 146, 147). У наведеному прикладі за допомогою термінолексем, що відносяться до різних сфер наукових знань, автор (Ю. Іздрик) намагається відтворити хід думок ліричного героя, який знаходиться у стані довготривалого алкогольного сп'яніння й до того ж утрачає свідомість. Терміни, що різняться сферою застосування, відбивають хаотичний на перший погляд потік свідомості, створюючи цим своєрідний стилістичний ефект (пор.: аритмія «порушення нормального ритму роботи серця» [10, с. 35]; Ірунтувати «покривати Грунтовкою полотно, призначене для живопису, або якусь поверхню, що готується для фарбування та нанесення спеціальної речовини» [10, с. 224]; пірке - «прищеплювання на шкірі, за допомогою якого встановлюють наявність або відсутність в організмі туберкульозної інфекції» [10, с. 672]; резонанс - «явище різкого зростання амплітуди вимушених коливань (електричних, магнітних, звукових тощо) в довільній коливальній системі, що настає в разі, коли змінна в часі зовнішня дія має гармонійні складові з частотою, близькою до однієї 3 частот власних коливань системи» [10, с. 757]).

Говорячи про використання термінологічних слів у художніх текстах, дослідники зазвичай акцентують на втраті термінів «своєї стилістичної замкненості» та їх використанні «у ролі складових елементів тропів і художніх образів» [3, с. 123]. Нами було помічено, що в постмодерних текстах тропеїзація термінів відбувається доволі рідко. Лише в окремих випадках ми спостерігали метафоризацію терміна: Отож иілком здаючи собі справу в однозначно сомнамбулічній природі довколишньої дійсності, я виліз на дах власного дому; знову вмошуюсь у своєму радіофікованому термодинамічному лігві (14, с. 106; 122). Інколи за допомогою науково-термінологічної лексики утворюється перифраза: невблаганне западання у вететативну прірву Альигаймера (3, с. 79), - назву однієї з хвороб нервової системи (хвороба Альцгаймера) замінено метафоричним описовим зворотом вететативна прірва Альцгаймера (пор.: «В. (вегетативна) нервова система - нервова система, волокна якої іннервують усі органи і тканини <..>> $[10$, с. 99]).

Натомість надзвичайно активно термінологічна лексика використовується письменниками-постмодерністами задля створення іронічного ефекту. Іронія присутня в багатьох постмодерних текстах; В. Пігулевський із цього приводу зауважив, що постмодерна іронія постає у вигляді пародії, перебільшення чи гротеску, зводячи певні стереотипи та () С. А. Бузько, 2012. 
кліше до карикатури та чорного гумору [7, с. 309]. Нами було виявлено, що одним із засобів створення іронії в постмодерних творах виступає науковотермінологічна лексика, наприклад: $Я$ переконався, щуо <..> можна любити всі ї̈ запахи. Що першим ранковим бажанням є не тотальна дезінфекція, а бажання поцілувати (13, с. 50) (дезінфекція - «заходи, спрямовані на знищення збудників інфекційних захворювань <..> $[10$, c. 231]). Тонке приховане глузування у поєднанні з гумором присутнє також у такому уривку: Віддавалася вона з таким запалом, ніби робила ие востанне в теперішній інкарнації, бо в наступній, вочевидь, вона мала стати якою-небудь рослиною, бажано корисною (7, с. 42).

Варто звернути увагу на те, що постмодерним творам властиві самоіронія та самопародіювання, при вираженні яких важливу роль відіграє добір спеціальних мовних засобів, зокрема слів-термінів. Одним iз найпоказовіших у цьому плані прикладів нам видається оцінювання Ю. Іздриком власної прози, елементи самооцінки знаходимо в одному 3 його творів: Ну щзо ж, все воно, звичайно, непогано, але иче якась така суиільна тягуча каша... Бракує йй, як на мене, якоїсь структурованості, може, виходів на певні узагальнення, я вже не кажу про такий критерій, як «катарсис». Замало у изьому всьому форми. Або хоча би вдалого закінчення. Це, звичайно, страшенно дотепно - винести епілог на початок (13, с. 52). Автор ніби глузує з себе, зі своєї повісті, називаючи іï «суцільною тягучою кашою», позбавленою цілого ряду необхідних для якісного літературного твору ознак. Не випадково акцент зроблено на слові «катарсис» (катарсис - «співпереживання читача або глядача, яке завершується духовним очищенням, духовною розрядкою» $[10$, с. 390$])$, це посилює іронічний відтінок висловлювання, адже навряд чи постмодерні тексти спрямовані на духовне очищення.

У ряді прикладів гумористично-іронічний ефект досягається завдяки поєднанню в межах одного текстового уривка науковотермінологічної та нелітературної лексики. У ролі нелітературних елементів можуть виступати як соціальні діалектизми, так і розмовнопросторічні слова (чи фразеологічні сполучення) зі зниженою конотацією пейоративного характеру, наприклад: Спочатку Сашко X. говорив про трансцендентування сегментів тогочасного дискурсу, а також про те, щуо ідеал досконалості <..> лежить в історичній процесуальності. $<\ldots>$ Після виступів Сашка у голові кумар, як після жирної косячини (20, с. 72); Після медитації Валерія повідомляла мені, щзо ї̈ карму повністю оновлено, і якщо я захочу, то можу ї̈ трахнути ще раз 
(7, с. 42); Що станеться, якшо просрати цюю субстанцію, звану долею, просто просрати - бездарно і нахабно, виклично (5, с. 22); Ії чоловік сидить на фенобарбіталі (26, с. 69). У наведених прикладах термінолексеми поєднуються у межах висловлювання зі стилістично зниженими елементами, значення яких подається у словниках жаргонної та сленгової лексики: кумар - «сонливість, фізіологічна апатія»; косяк «сигарета 3 марихуаною»; трахати - «здійснювати статевий акт»; просирати - «втрачати, розбазарювати»; сидіти (на чому?) - «постійно вживати наркотичні речовини» [9, с. 174, 170, 294, 257, 272].

На думку В. Чабаненка, саме від наявності одиниць, які контрастують, залежить мовна експресія в контекстуальних умовах, оскільки різностильові контрасти збагачують емоційну палітру тексту, збільшують його експресивну напругу, роблять мовлення стилістично гнучким та поліфонічним [11, с. 14-18].

Невисоким ступенем активності в постмодерних текстах відзначається так звана висока лексика словесно-художнього зображення, або поетична, з якою асоціюються особливі, небуденні уявлення і яка зазвичай використовується в поетичному мовленні або у виступах ораторів, коли виправдовується патетичний, урочистий тон.

У власне номінативному значенні подібна книжно-урочиста лексика використовується в постмодерних творах у досить обмеженій кількості - у тих текстових уривках, які потребують присутності слів, що здатні викликати яскраві уявлення та асоціації, наприклад: Здавалося, що все те залізяччя тікало, розповзаючись на всі боки та шукаючи самоти й супокою в прохолодних нетрях бур'янів, щзоб спокійно дійти небуття (9, с. 44); Чому любовні історії мають обов'язково складатися з мук і гіркоти (1, с. 38); $А$ втім, любов - яке ж це горе? Це блаженство. Це світла радість, иум у голові, ие найвище щиастя, ие благословення (21, с. 131); йому було далеко до колишніх закарпатських трунків (14, с. 150). У наведених прикладах поетизми надають викладові певної урочистості та піднесеності, завдяки чому в читача виникають додаткові асоціації. У звичайному розмовному мовленні замість цих лексем використовують нейтральні 3 боку стилістичної маркованості синоніми (пор.: самота - самотність; супокій - спокій; доходити небуття - переставати жити, помирати; мука, гіркота - страждання; блаженство - насолода; трунок - запах).

Як відомо, до складу книжної поетичної лексики входять старослов'янізми, які надають мовленню особливого урочистого ๑) С. А. Бузько, 2012. 
відтінку; в окремих випадках використовуються вони й у текстах української постмодерної прози: Панна Фрузя мала осину талію, над якою нависали повні перса, а нижче випинало круте узгір'я стегон; русалка <..> висунулась так, що з'явилися ї̈ білі витончені рамена $(9$, c. 70,107$)$ (перса - «заст. Жіночі груди» [10, с. 653]; рамено «заст. Плече» [10, с. 750]).

Але функцію створення певної урочистості й піднесеності поетична лексика виконує в постмодерністських текстах доволі рідко. Зазвичай поетизми, як і слова-терміни, використовуються в текстах української постмодерної прози 3 протилежною метою створення іронічних та гумористичних ефектів, тобто виконують не властиву їм функцію, наприклад: Заклад пропонував цілий вибір українських коньяків. Україна - благословенна країна в изьому сенсі (21, с. 299); Четверта користь - чоловіка можна використати в якості шофера та опори, якщо вам спав на думку блаж одягнути вузьку спідницю $i$ туфлі на високих підборах (20, с. 53); прискіпливо оглядаючи себе у дзеркалі чи, поетично мовлячи, у свічаді (23, с. 27).

Інколи гумористично-іронічний ефект досягається завдяки поєднанню в межах висловлювання книжно-поетичної та розмовнопобутової лексики (чи загальновживаної 3 відтінком розмовності); урочистий відтінок книжно-поетичних лексем у такому разі контрастує 3 побутовізмом описуваних ситуацій, що створює додатковий стилістичний ефект: Сміттярка займає настільки велику територію, щзо в неї чимало теренів узагалі ще незвіданих (9, с. 60); Хлопчина той, ясночолий улюбленець вахтерки (14, с. 149); I сто грамів копченої мойви, $i$ пляшку бальзаму «Тарас Шевченко». Вшануємо пам'ять пророка (20, с. 22); перший обпік потрісканих уст... (а добрий коньяк завжди потрапляє на потріскані уста) $(14$, с. 150$)$.

В інших подібних випадках експресивно-стилістичний ефект породжується зіткненням поетичної та стилістично зниженої розмовнопросторічної або соціально маркованої лексики. Добір елементів, що контрастують, залежить від задуму автора та стилістичної заданості вислову. Спрямованість постмодерних текстів на іронію вимагає зіткнення не рівноправних у стилістичному та соціолінгвістичному плані мовних одиниць, як-от у таких прикладах: Віднайшовши спочин $y$ Владивостоиі, він назавжди закрив свій тонкогубий писок (26, с. 37); до нас долинали лише примарні тіні, світляні привиди, дурепи осяйні (13, с. 12). Виділені лексеми в «Сучасному тлумачному словнику 
української мови» позначені відповідними ремарками: спочити - «уроч. Бути мертвим, лежати в могилі» [10, с. 825]; писок - «розм. 1. Те саме, що морда; перен., вульг. Потворне людське обличчя» [10, с. 617]; осяйний - «nоет. Освітлений, опромінений чимось; який випромінює сяйво, сяючий, променистий» [10, с. 616]; дурепа - «зневажл., лайл. Розумово обмежена жінка» $[10$, с. 271]. Подібне свідоме протиставлення різностильових лексичних одиниць не лише підкреслює іронічність викладу, але й допомагає ідейно та експресивно наснажити художній текст. «Лінгвостилістика контрастів <..> відбиває тонкі й складні нюанси, що характеризують специфіку авторського стилю, специфіку художньої манери письменника. <..> Саме на видобування нових, свіжих, оригінальних якостей контрасту часто й направлені його творчі зусилля» $[11$, с. 50]. Аналіз дібраного матеріалу доводить, що лінгвостилістичні контрасти (передусім контрастування різностильових мовних одиниць) значною мірою визначають специфіку української постмодерної прози, становлять одну з ії характерних ознак.

Крім цього, велика кількість лінгвостилістичних контрастів, що були помічені нами в постмодерних текстах, свідчить про відсутність внутрішньої замкнутості в лексичній системі сучасної української мови та наявність тенденції до взаємопроникнення й синтезу лексичних одиниць різних рівнів. Також це $є$ свідченням активної взаємодії на лексичному рівні усного побутового мовлення та мови сучасної художньої літератури; «контрастування елементів мовної системи є водночас і формою їх взаємозв'язку <..> мовний контраст це не просто об'єктивна лінгвістична універсалія, а ще універсалія лінгвостилістична, породжена суб'єктивними мовотворчими зусиллями мовця в його пошуках експресивних засобів вислову» [11, с. 13-14]. Важливо відзначити, що для обох учасників комунікативного процесу (автор - читач) важливим $є$ не мовний контраст сам по собі, а його виражальні можливості та стилістична вагомість.

Також привертають увагу в текстах постмодерної прози спільнокореневі поетизми, які використовуються в межах словосполучення, однак сприймаються не як тавтологія, а як гра слів, загалом характерна для постмодерністських текстів: a він тим часом добирається до моєї потаємної потаємності, до моєї святенної святенності, до моєї невтішної невтішності, до моєї лелійної лелійності, до моєї непорочної непорочності (9, с. 119). На противагу ๑) С. А. Бузько, 2012. 
нормативному мовному стандарту, згідно 3 яким тавтологічні звороти збіднюють лексичний склад висловлення й негативно характеризують мовця, у художніх текстах такі прийоми, навпаки, увиразнюють мовлення, оскільки використовуються із заданістю на певний стилістичний ефект.

Отже, найбільш уживаними в текстах української постмодерної прози виявилися такі типи книжної лексики, як суспільно-політична, термінологічна та поетична. Функціонування в постмодерних текстах різних тематичних груп суспільно-політичної лексики зумовлюється передусім потребою відтворити об'єктивну дійсність у поєднанні 3 суб'єктивно-авторським осмисленням цієї дійсності. Уживання загальнонаукової та вузькоспеціальної термінологічної лексики пояснюється певною спрямованістю постмодерних текстів на елітарність та інтелектуальність; помітний перехід деяких термінологічних лексем до розряду загальновживаних (детермінологізація). Характерною особливістю використання в постмодерних текстах названих лексичних шарів $є$ поєднання в межах словосполучення або висловлювання різностильових лексичних елементів - зазначених груп книжної лексики (суспільно-політичної, науково-термінологічної або поетичної) 3 різними типами нелітературної (зокрема розмовно-просторічною та соціально маркованою лексикою), у результаті чого, як правило, створюється іронічний ефект. Широке застосування письменникамипостмодерністами цього прийому свідчить про відсутність внутрішньої замкнутості та наявність тенденції до взаємопроникнення й синтезу різнопланових одиниць у лексичній системі сучасної української мови; якоюсь мірою це також зближує розмовно-побутову суспільну практику з дискурсом художньої літератури.

\section{Література}

1. Бабич Н. Д. Практична стилістика і культура української мови : [навч. посібн.] / Н. Д. Бабич. - Львів : Світ, 2003. - 430 с.

2. Бельчиков Ю. А. Лексическая стилистика: проблемы изучения и обучения / Ю. А. Бельчиков. - М. : Русский язык, 1988. - 158 с.

3. Карпова В. Л. Термін і художнє слово / В. Л. Карпова. - К. : Наукова думка, 1967. $-129 \mathrm{c}$.

4. Костенко Л. Україна як жертва і чинник глобалізації катастроф / Л. Костенко // Дві русі / [за заг. ред. Л. Івшиної]. - К. : Факт, 2003. - С. 455-467.

5. Лізлова С. А. Гра в постмодерністському творі: на матеріалі творчості Ю. Андруховича : автореф. дис. на здобуття наук. ступеня канд. філол. наук : спец. 10.01.06 «Теорія літератури» / С. А. Лізлова - К., 2004. -23 с. 
6. Мінасян В. І. Терміни в поезіях М. Бажана / В. І. Мінасян // Культура слова : [республ. міжвід. зб.] - К. : Наукова думка, 1983. - Вип. 25. - С. 17-20.

7. Пигулевский В. Ирония и вымысел: от романтизма к постмодернизму / В. О. Пигулевский. - Ростов-на-Дону : Фолиант, 2002. - 415 с.

8. Пікун Л. Дзеркальна гра набутками культури як явище літературного постмодернізму / Л. Пікун // Слово і Час. - 2005. - № 11. - С. 40-47.

9. Словник сучасного українського сленгу [упорядн. Т. М. Кондратюк]. - Харків : Фоліо, 2006. - 350 с.

10. Сучасний тлумачний словник української мови / [за заг. ред. В. В. Дубічинського]. - Харків : ВД «Школа», 2008. - 1008 с.

11. Чабаненко В.А. Стилістика експресивних засобів української мови / В. А. Чабаненко. - Запоріжжя, 2002. - 351 с.

12. Чередниченко І. Г. Нариси з загальної стилістики сучасної української мови / I. Г. Чередниченко. - К. : Радянська школа, 1962. - 495 с.

\section{Список використаних джерел}

1. Андрухович С. Жінки їхніх чоловіків / Софія Андрухович. - Івано-Франківськ : Лілея-НВ, 2005. - 160 с.

2. Андрухович С. Сьомга / Софія Андрухович. - К. : Факт, 2007. - 384 с.

3. Андрухович Ю. Рекреації : [романи] / Юрій Андрухович. - К. : «Вид-во «Час», 1997. - 287 c.

4. Андрухович Ю. Дванадцять обручів / Юрій Андрухович. -К. : Критика, 2003. - 317 с.

5. Бриних М. Електронний пластилін : [повість] / Михайло Бриних. - К. : Факт, 2007. $-244 \mathrm{c}$.

6. Бриних М. Шахмати для дибілів : [роман-посібник] / Михайло Бриних. - К. : Факт, 2008. - 144 c.

7. Винничук Ю. Весняні ігри в осінніх садах / Юрій Винничук. - Харків : Книжковий клуб «Клуб Сімейного Дозвілля», 2007. - 288 с.

8. Винничук Ю. Житіє гаремноє / Юрій Винничук. - Львів : ЛА «Піраміда», 1996. - 104 с.

9. Винничук Ю. Мальва Ланда / Юрій Винничук. - Львів : ЛА «Піраміда», 2003. - 540 с.

10. Жадан С. Капітал / Сергій Жадан. - Харків : Фоліо, 2006. - 797 с.

11. Жолдак Б. Гальманах / Богдан Жолдак. - К. : Факт, 2007. - 248 с.

12. Забужко О. Польові дослідження 3 українського сексу : [роман] / Оксана Забужко. - [9-е вид.] - К. : Факт, 2007. - 176 с.

13. Іздрик Ю. Острів Крк та інші історії : [повість, новели, автокомента / Юрій Іздрик. - Івано-Франківськ : Лілея-НВ, 1998. - 120 с.

14. Іздрик Ю. Подвійний Леон / Юрій Іздрик. - Івано-Франківськ : Лілея-НВ, 2000. - 204 с.

15. Ірванець О. Очамимря : [повість та оповідання] / Олександр Ірванець. - К. : Факт, 2003. - 184 c.

16. Ірванець О. Рівне / Ровно (стіна) : [нібито роман] / Олександр Ірванець. - Львів : Кальварія, 2002. - 189 с.

17. Карпа I. 50 хвилин трави : [новели] / Ірена Карпа. - Львів : Кальварія, 2006. - 238 с.

18. Матіос М. Містер і місіс Ю-Ко в країні укрів. Mr. \& Ms. U-Ko in country UA / Марія Матіос. - Львів : ЛА «Піраміда», 2006. - 136 с.

19. Пагутяк Г. Писар східних воріт притулку / Галина Пагутяк. - Львів : ЛА «Піраміда», 2003. - 176 с. 
20. Пиркало С. Зелена Маргарита : [повість, оповідання] / Світлана Пиркало. - К. : Факт, 2007. - 184 с.

21. Пиркало С. Не думай про червоне : [роман не для молодшого шкільного віку] / Світлана Пиркало. - [2-е вид.] - К. : Факт, 2006. - 360 с.

22. Поваляєва С. Ексгумація міста : [новели] / Світлана Поваляєва. - Львів: Кальварія, 2006. -160 с.

23. Процюк С. Жертвопринесення : [роман] / С. Процюк // Кур’єр Кривбасу. 2003. - № 161. - C. 23-102.

24. Ульяненко О. Серафима : [роман] / Олесь Ульяненко. - К. : Нора-Друк, 2007. - 240 с. 25. Ушкалов С. БЖД : [crazynovel] / Сашко Ушкалов. - [2-е вид.] - К. : Факт, 2008. - 240 с. 26. Чех А. Цього ви не знайдете в Яндексі / Артем Чех. - Харків : Фоліо, 2007. - 218 с. 27. Прохасько Т. Лексикон / Тарас Прохасько. - Львів : Кальварія, 2004. - 187 с.

Стаття надійшла до редакції 31.10.2012 p. 